\title{
Ksztaltowanie postaw przedsiębiorczych na lekcjach geografii wyzwaniem edukacyjnym w procesach globalizacji
}

W procesie kształtowania społeczeństwa informacyjnego oraz procesach globalizacyjnych istotną rolę odgrywa wiedza i nauka, a kapitał ludzki jest czynnikiem, bez którego nie jest możliwe osiągnięcie trwałego i wysokiego tempa rozwoju społeczno-gospodarczego (m.in. Borowiec 2003, 2009, 2010; Chojnicki, Czyż 2008; Harańczyk 2008; Janc 2003; Zioło 2009, 2010). Cywilizacja informacyjna jest cywilizacją szybkich zmian, co oznacza konieczność reagowania na nowe uwarunkowania, a siłą motoryczną jej rozwoju są zasoby kapitału ludzkiego (Kołodziejski 1998). Jak przyjmuje I. Zioło: „współczesne wyzwania cywilizacyjne stawiają nowe, wysokie zadania w zakresie edukacji i przygotowania do pełnienia określonych ról zawodowych. Zadania edukacji są bowiem determinowane rozwojem społecznym, gospodarczym i kulturalnym, stanem świadomości społecznej oraz potrzebami i zainteresowaniami ludzi żyjących w określonych strukturach społeczno-ekonomicznych. One wyznaczają zasadnicze priorytety polityki oświatowej oraz konstrukcję systemu edukacji” (Zioło 1999, s. 127). Zadaniem edukacji jest przygotowanie ludzi do adaptacji w nowych uwarunkowaniach społeczno-gospodarczych, tak aby mogli oni w sposób racjonalny wpływać na struktury, które dziś podlegają przemianom. Umożliwia to jak zakłada L. Kuźnicki (2004) realizację głównego megatrendu współczesnego procesu rozwoju jakim jest budowa gospodarki opartej na wiedzy.

Zdaniem A. Wielońskiego (2003), przyspieszenie w ostatnich latach budowy gospodarki opartej na wiedzy wynika w dużej mierze ze zwiększającego się znaczenia innowacyjności we współczesnej gospodarce. Prowadzi to do wzrostu roli wiedzy jako czynnika, od którego zależy przyszły rozwój społeczeństw, przedsiębiorstw, instytucji i gospodarek krajowych w fazie informacyjnego rozwoju. Występuje tu rodzaj sprzężenia zwrotnego między innowacyjnością technologiczną a wzrostem zapotrzebowania na wiedzę. Postęp technologiczny staje się podstawą rozwoju społeczeństwa i gospodarki. Konkurencja w tym zakresie między korporacjami międzynarodowymi powoduje nasilenie się presji na systematyczne przyspieszanie rozwoju nauki i technologii, gdyż - zdaniem A. Wielońskiego (2003) - to właśnie kapitał intelektualny jest podstawą przewagi konkurencyjnej przedsiębiorstw we współczesnej gospodarce. Nasilenie się presji konkurencyjnej w układzie globalnym wymusza na przedsiębiorstwach ciągłe podnoszenie efektywności produkcji, odbywające się m.in. poprzez podnoszenie kwalifikacji i wykształcenia pracowników przedsiębiorstw, a także instytucji otoczenia.

Podobnie M. Kabaj (1997) podkreśla, że ważne miejsce w postępie technologicznym, gospodarczym i społecznym zajmuje rozwój i doskonalenie kwalifikacji zasobów ludzkich, tworzenie i wykorzystywanie wiedzy. Produktywność, konkurencyjność i efektywność zależą 
od zasobu i nowoczesności wiedzy ludzi, od jakości pracy, wykształcenia, umiejętności ciągłego myślenia innowacyjnego i wdrażania nowych rozwiązań do procesów wytwarzania, dystrybucji oraz usług. W dobie silnego postępu technologicznego zaniechanie tych dostosowań skazuje uczestników procesów globalizacji na marginalizację (Zajączkowska-Jakimiak 2002). W konsekwencji kraje, które szybciej dokonują transformacji w kierunku gospodarki opartej na wiedzy, uzyskują przewagę w globalnej gospodarce światowej. Z kolei N. Juszkiewicz uważa, że w cywilizacji informacyjnej na znaczeniu zyskuje wiele nowych czynników rozwoju społeczno-gospodarczego, a za jeden z najważniejszych uznaje się poziom szkolnictwa i rozwoju nauki. Zdaniem autorki „można zatem przyjąć tezę, że wyniki funkcjonowania systemu nauki i szkolnictwa, w szczególności szkolnictwa wyższego, w postaci ilości i jakości kadr na każdym poziomie przygotowania zawodowego, są czynnikiem decydującym o kierunkach i poziomie rozwoju gospodarczego i społecznego oraz jego konkurencyjności” (Juszkiewicz 1997, s. 211). „Edukacja powoduje poprawę życia, podnosząc jego jakość i prowadzi do zwiększenia korzyści społecznych. Oświata zwiększa poziom produktywności i kreatywności jednostek, daje impuls do nowych inicjatyw, wyzwala przedsiębiorczość i postęp techniczny [...] Zauważono także, że żadnemu państwu współczesnego świata nie udało się podtrzymanie ekonomicznego rozwoju bez znacznej inwestycji w kapitał ludzki” (Grodzicki 2000, s. 6).

Rolę wiedzy jako czynnika podnoszącego konkurencyjność gospodarki podkreślono w przyjętej w 2000 r. strategii lizbońskiej, której głównym celem jest zwiększenie konkurencyjności europejskiej gospodarki poprzez rozwój gospodarki opartej na wiedzy oraz stworzenie warunków do wzrostu przedsiębiorczości (Kafel 2005). Osiągnięcie tego celu jest możliwe dzięki podjęciu działań edukacyjnych przedstawionych w programie prac Edukacja i szkolenia 2010 przyjętym przez ministrów edukacji UE i Komisję Europejską w 2002 r. Wyróżniono w nim następujące cele strategiczne:

1. ,poprawa jakości i efektywności systemów edukacji w UE wobec nowych zasad społeczeństwa opartego na wiedzy oraz zmieniających się metod i treści nauczania i uczenia się" (Strategia MENiS, s. 5),

2. działanie na rzecz zwiększenia szans zdobycia i utrzymania zatrudnienia oraz rozwoju zawodowego,

3. lepsze dostosowanie edukacji do potrzeb pracy zawodowej i wymagań społeczeństwa oraz sprostania wymaganiom wynikającym z globalizacji.

Mając na uwadze założenia strategii lizbońskiej, już w Narodowym planie rozwoju na lata 2004-2006 założono rozwijanie konkurencyjnej gospodarki opartej na wiedzy i przedsiębiorczości. Podobnie kierunki, przedsięwzięcia i działania Priorytetu Wiedza i Kompetencje ${ }^{1}$ za- $^{-}$ wartego w Narodowym planie rozwoju na lata 2007-2013 obejmują: zwiększenie dostępu do edukacji, wyższą jakość kształcenia oraz wspieranie otwartości systemu edukacji realizowane m.in. poprzez kształtowanie postaw przedsiębiorczych, innowacyjnych i proekologicznych.

Strategia rozwoju edukacji na lata 2007-2013 zakłada, że edukacja w Polsce jako integralny system kształcenia (umożliwianie zdobycia wiedzy i umiejętności) oraz wychowania (kształtowanie i promowanie postaw) będzie: ułatwiać każdemu realizację aspiracji, rozwój i wykorzystanie możliwości, przygotowywać do aktywnego i odpowiedzialnego uczestniczenia w życiu społecznym, kulturalnym i gospodarczym (w wymiarze lokalnym, narodowym i globalnym), skutecznie przeciwdziałać wykluczeniu i marginalizacji osób oraz grup społecznych, reagować na zmiany związane z rozwojem nauki, nowoczesnych technologii i globalizacją,

\footnotetext{
${ }^{1}$ Priorytet Wiedza i Kompetencje rozumiany jest jako poprawa jakości kształcenia i jego upowszechnienie na poziomie średnim i wyższym.
} 
szybko i elastycznie dostosowywać się do zmian zachodzących na rynku pracy. Jak przyjmuje J. Ratajczak: „nie kształcimy bowiem tylko na potrzeby własnej gospodarki, choć jest to celem priorytetowym, ale także na potrzeby zintegrowanej Europy, która dla prawidłowego rozwoju potrzebuje wysoko kwalifikowanych kadr, ludzi zdolnych do innowacji, przedsiębiorczych i zdolnych do kształcenia ustawicznego" (Ratajczak 2005, s. 296).

W świetle powyższych rozważań rodzi się pytanie o to, czy system edukacji szkolnej, w tym kształcenie geograficzne, odpowiada na współczesne wyzwania cywilizacyjne i przygotowuje młodego człowieka do adaptacji w nowych warunkach rozwoju społeczno-gospodarczego, tak aby potrafił on w sposób racjonalny wpływać na podlegające dziś przemianom struktury. Należy przyjąć, że kluczową sprawą w przygotowaniu do życia we współczesnej cywilizacji informacyjnej jest kształtowanie postaw przedsiębiorczych. Za sprawą przyspieszenia rozwoju nauki wynikającego z postępu technologicznego nie sposób bowiem założyć, iż tylko w toku edukacji szkolnej uda się przygotować uczniów do odnalezienia swojego miejsca w świecie, czyli m.in. do wejścia na rynek pracy. Bardzo często wiedza i umiejętności zdobyte w szkole już w momencie jej opuszczenia są niewystarczające do wykazania aktywności zawodowej i wymagają ciągłego aktualizowania. Jest to konieczne nie tylko w wypadku technologii informacyjnej, ale także w wypadku innych przedmiotów szkolnych, w tym geografii. Dzięki kształtowaniu postaw przedsiębiorczych w toku edukacji młody człowiek będzie coraz bardziej rozumiał potrzebę ustawicznego kształcenia poprzez aktualizowanie wiedzy i zdobywanie nowych umiejętności, co pozwoli mu uniknąć marginalizacji w społeczeństwie fazy informacyjnej. Należy tu jednak podkreślić, że nie chodzi o wąskie ujęcie przedsiębiorczości rozumianej często jako zdolność do założenia i poprowadzenia własnej firmy. Chodzi o szersze rozumienie postawy przedsiębiorczej jako: a) zespołu cech osobowych człowieka, takich jak: aktywność, wytrwałość, zapał do pracy, inicjatywa, kreatywność, asertywność, zdolność do koncentracji, pewność siebie i wiara we własne siły, samodyscyplina, uczciwość, skłonność do wyważonego ryzyka oraz brania odpowiedzialności za siebie i innych, postępowanie zgodne z zasadami etycznymi, b) zespołu posiadanych umiejętności, np. wyszukiwania i wykorzystywania szans, które stwarza rynek, stawiania i realizowania wyznaczonych sobie celów poprzez wytyczanie własnej ścieżki kariery zawodowej, zdobywania, selekcji i przetwarzania informacji, interpretowania procesów gospodarczych, rozumienia związków przyczynowo-skutkowych, z zakresu autoprezentacji, komunikacji interpersonalnej itp. Cechy te pozwalają dobrze prowadzić przedsiębiorstwo, tj. być dobrym przedsiębiorcą, oraz aktywnie uczestniczyć w życiu społeczno-gospodarczym (w tym życiu rodzinnym), co umożliwia osiągnięcie satysfakcji, niezależnie od charakteru wykonywanej pracy i zajmowanego stanowiska. Człowiek przedsiębiorczy nie boi się trudności, podejmowania nowych, nieznanych zadań, nie załamuje się niepowodzeniami, jest chętny do zdobywania wiedzy i nowych umiejętności, potrafi cieszyć się z sukcesów, jest otwarty na otoczenie, empatyczny, gotowy do współpracy z innymi ludźmi i postępuje zgodnie z wartościami etycznymi (Borowiec 2005; Rachwał 2004, 2005).

Taki punkt widzenia postawy przedsiębiorczej jest powszechnie przyjmowany przez wielu autorów. Warto tu przytoczyć słowa D. Golemana: „Skoro zmienia się gospodarka, zmieniają się również cechy potrzebne do przetrwania w niej, nie mówiąc już o odnoszeniu sukcesów. [...] Nacisk ze strony konkurencji każe docenić ludzi, którzy potrafią się sami motywować do działania, wykazują inicjatywę, odczuwają wewnętrzną potrzebę prześcignięcia samych siebie i mają tyle optymizmu, że nie zniechęcają się niepowodzeniami i porażkami, lecz uporczywie kroczą naprzód" (Goleman 1999, s. 434). Człowiek przyjmujący postawę przedsiębiorczą jest więc według D. Golemana $(1999,1997)$ bezcennym skarbem dla każdej firmy 
i instytucji. Intensywne przemiany gospodarcze i konieczność nieustannego podnoszenia konkurencyjności przedsiębiorstw oraz instytucji wymagają zatem kształtowania u uczniów - późniejszych pracowników - w ten sposób rozumianej postawy przedsiębiorczości.

Postawa ta kształtowana jest nie tylko przez nauczycieli w szkole, ale także w rodzinie, już od najmłodszych lat, w toku całego procesu kształcenia młodzieży. W wypadku edukacji szkolnej, według nowej koncepcji systemu oświaty, pewne elementy tej postawy powinny pojawić się już w szkole podstawowej, ale zasadniczy nacisk kładzie się na etap szkoły gimnazjalnej i ponadgimnazjalnej. W tym celu podjęto decyzję o wprowadzeniu do edukacji szkolnej modułu wychowanie do aktywnego udziału w życiu gospodarczym w ramach WOS w gimnazjum (obecnie, tj. od 2009 r., zrezygnowano z tej nazwy, ale treści w ramach WOS zostały pozostawione) oraz osobnego przedmiotu podstawy przedsiębiorczości w szkołach ponadgimnazjalnych. W założeniach nowego systemu edukacji właśnie w tych przedmiotach ma się koncentrować edukacja w zakresie przedsiębiorczości. Jednakże wydaje się, że nie jest możliwe zrealizowanie celu głównego zajęć w ciągu zaledwie dwóch czy trzech godzin w cyklu kształcenia (uwzględniając łącznie etap gimnazjum i szkoły ponadgimnazjalnej). Wielką rolę w tym względzie mają więc do odegrania wychowawcy i nauczyciele podejmujący studia podyplomowe z zakresu przedsiębiorczości, w celu zdobycia kwalifikacji do nauczania podstaw przedsiębiorczości (Makieła 2004a, b; Rachwał 2004). Jednak nie tylko lekcje podstaw przedsiębiorczości, ale także lekcje geografii, zajęcia fakultatywne i różnego typu zajęcia pozalekcyjne organizowane przez nauczycieli geografii stwarzają możliwości kształtowania postaw przedsiębiorczych.

Po przeanalizowaniu aktualnie obowiązującej podstawy programowej geografii widać, że z postawą przedsiębiorczości w gimnazjum wiąże się IV cel kształcenia, określony jako „Kształtowanie postaw" (Rozporzadzenie 2009). Obrazuje to tabela 1, w której podkreślono ważniejsze treści związane z przedsiębiorczością.

Tab. 1. Cele kształcenia z zakresu geografii a kształtowanie postaw przedsiębiorczych (gimnazjum)

\begin{tabular}{|l|l|}
\hline \multicolumn{1}{|c|}{$\begin{array}{c}\text { Cele kształcenia - wymagania ogólne - } \\
\text { wg podstawy programowej }\end{array}$} & \multicolumn{1}{c|}{$\begin{array}{c}\text { Wybrane cechy i umiejętności } \\
\text { osoby przedsiębiorczej* }\end{array}$} \\
\hline $\begin{array}{l}\text { „Uczeń rozwija w sobie: ciekawość świata poprzez } \\
\text { zainteresowanie własnym regionem, Polską, Europa } \\
\text { i światem [...]” }\end{array}$ & $\begin{array}{l}\text { otwartość na otoczenie, ciekawość świata, } \\
\text { umiejętność wyszukiwania i wykorzystywania } \\
\text { szans, które stwarza rynek (regionalny, krajowy, } \\
\text { europejski, światowy) }\end{array}$ \\
\hline $\begin{array}{l}\text { „Uczeń rozwija w sobie: [...], świadomość wartości i poczucie odpowiedzialności za środowisko } \\
\text { przyrodnicze i kulturowe własnego regionu i Polski; } \\
\text { patriotyzm i poczucie tożsamości (lokalnej, } \\
\text { regionalnej, narodowej) przy jednoczesnym } \\
\text { poszanowaniu innych narodów i społeczności }- \\
\text { ich systemów wartości i sposobów życia.” }\end{array}$ & $\begin{array}{l}\text { postępowanie zgodne z wartościami etycznymi } \\
\text { (w tym szacunek dla innych), odpowiedzialność } \\
\text { za siebie i innych, umiejętności z zakresu } \\
\text { komunikacji interpersonalnej (rozwiązywanie } \\
\text { konfliktów, prowadzenie negocjacji) }\end{array}$ \\
\hline
\end{tabular}

*możliwe do kształtowania w toku realizacji danego celu kształcenia

Źródło: opracowanie własne na podstawie Rozporządzenie 2009.

Wiedza i umiejętności związane z przedsiębiorczością mogą być kształtowane na lekcjach geografii w gimnazjum w ramach zajęć realizujących treści nauczania z zakresu geografii gospodarczej Polski i Europy. Podstawa programowa (Rozporządzenie 2009) zakłada w tym zakresie realizację następujących treści nauczania - wymagań szczegółowych: 


\section{Wybrane zagadnienia geografii gospodarczej Polski. Uczeń:}

1) wyróżnia główne cechy struktury użytkowania ziemi, wielkości i własności gospodarstw rolnych, zasiewów i hodowli w Polsce na podstawie analizy map, wykresów, danych liczbowych [podkreślenia - M. B., T. R.];

2) podaje przyczyny zróżnicowania w rozmieszczeniu wybranych upraw (pszenicy, ziemniaków, buraków cukrowych) oraz chowu bydła i trzody chlewnej w Polsce;

3) przedstawia, na podstawie różnych źródeł informacji, strukturę wykorzystania źródeł energii w Polsce i ocenia jej wpływ na stan środowiska przyrodniczego;

4) wyjaśnia przyczyny zmian zachodzacych w przemyśle w Polsce i we własnym regionie oraz wskazuje najlepiej rozwijające się obecnie w Polsce gałęzie produkcji przemysłowej;

5) rozróżnia rodzaje usług; wyjaśnia szybki rozwój wybranych usług w Polsce i we własnym regionie;

6) wykazuje na przykładach walory turystyczne Polski oraz opisuje obiekty znajdujące się na Liście światowego dziedzictwa kulturowego i przyrodniczego UNESCO;

7) opisuje na podstawie map i wyjaśnia zróżnicowanie gęstości i jakości sieci transportowej w Polsce i wykazuje jej wpływ na rozwój innych dziedzin działalności gospodarczej;

8) wykazuje konieczność ochrony środowiska przyrodniczego i kulturowego w Polsce; wymienia formy jego ochrony, proponuje konkretne działania na rzecz jego ochrony we własnym regionie.

Europa. Relacje przyroda - czlowiek - gospodarka. Uczeń:

1) wykazuje się znajomością podziału politycznego Europy;

2) określa położenie Europy i główne cechy środowiska przyrodniczego na podstawie mapy ogólnogeograficznej i map tematycznych;

3) opisuje, na podstawie map tematycznych, zróżnicowanie regionalne, kulturowe, narodowościowe i etniczne współczesnej Europy oraz najważniejsze przyczyny i konsekwencje tego zróżnicowania;

4) wykazuje, na podstawie map tematycznych, związki między głównymi cechami środowiska przyrodniczego Europy Północnej a głównymi kierunkami rozwoju gospodarczego;

5) wykazuje, na przykładzie rolnictwa Francji lub innego kraju europejskiego, związek pomiędzy warunkami przyrodniczymi a kierunkiem i efektywnością produkcji rolnej; identyfikuje cechy rolnictwa towarowego;

6) przedstawia, na podstawie wskazanych źródeł informacji geograficznej, główne kierunki i przyczyny zmian w strukturze przemysłu wybranego regionu (lub okreggu) przemysłowego w Europie Zachodniej;

7) przedstawia główne cechy położenia, wielkości, układu przestrzennego oraz znaczenie Paryża lub Londynu jako światowej metropolii;

8) wykazuje wpływ gór na cechy środowiska przyrodniczego oraz gospodarkę krajów alpejskich;

9) wykazuje związki między rozwojem turystyki w Europie Południowej a warunkami przyrodniczymi oraz dziedzictwem kultury śródziemnomorskiej;

10) prezentuje opracowana na podstawie map, przewodników, Internetu trase wycieczki po Europie lub jej części.

Wybrane regiony świata. Relacje: człowiek - przyroda - gospodarka. Uczeń:

1) wykazuje, na podstawie map tematycznych, że kontynent Azji jest obszarem wielkich geograficznych kontrastów;

2) przedstawia, na podstawie map tematycznych, warunki przyrodnicze obszarów, na których kształtowały się najstarsze azjatyckie cywilizacje;

3) analizuje wykresy i dane liczbowe dotyczące rozwoju ludnościowego i urbanizacji w Chinach; wyjaśnia, na podstawie map tematycznych, zróżnicowanie rozmieszczenia ludności 
na obszarze Chin; podaje kierunki rozwoju gospodarczego Chin oraz wskazuje zmiany znaczenia Chin w gospodarce światowej;

4) wykazuje znaczenie czynników społeczno-kulturowych w tworzeniu nowoczesnej gospodarki Japonii na tle niekorzystnych cech środowiska przyrodniczego;

5) wykazuje związek pomiędzy rytmem upraw i „kulturą ryżu” a cechami klimatu monsunowego w Azji Południowo-Wschodniej;

6) opisuje kontrasty społeczne i gospodarcze w Indiach; wyjaśnia przyczyny gwałtownego rozwoju nowoczesnych technologii;

7) charakteryzuje region Bliskiego Wschodu pod kątem cech kulturowych, zasobów ropy naftowej, kierunków i poziomu rozwoju gospodarczego; wskazuje miejsca konfliktów zbrojnych;

8) charakteryzuje na podstawie map tematycznych i wyjaśnia występowanie stref klimatyczno-roślinno-glebowych w Afryce;

9) wykazuje, na przykładzie strefy Sahelu, związek pomiędzy formami gospodarowania człowieka a zasobami wodnymi; uzasadnia potrzebe racjonalnego gospodarowania w środowisku charakteryzującym się poważnymi niedoborami słodkiej wody;

10) określa związki pomiędzy problemami wyżywienia, występowaniem chorób (m.in. AIDS) a poziomem życia w krajach Afryki na południe od Sahary;

11) wyróżnia główne cechy i przyczyny zróżnicowania kulturowego i etnicznego Ameryki Północnej i Południowej;

12) identyfikuje konflikt interesów pomiędzy ekologicznymi skutkami wylesiania Amazonii a jej gospodarczym wykorzystaniem; określa cechy rozwoju i problemy wielkich miast w Brazylii;

13) wykazuje związki między gospodarka a warunkami środowiska przyrodniczego w najważniejszych regionach gospodarczych Stanów Zjednoczonych; określa rolę Stanów Zjednoczonych w gospodarce światowej;

14) przedstawia, na podstawie map tematycznych, główne cechy gospodarki Australii na tle warunków środowiska przyrodniczego;

15) przedstawia cechy położenia i środowiska geograficznego Antarktyki i Arktyki; podaje główne cechy i przyczyny zmian w środowisku przyrodniczym obszarów okołobiegunowych.

Widać również związki między kształtowaniem postawy przedsiębiorczej a celami edukacji geograficznej na poziomie szkoły ponadgimnazjalnej, gdzie dwa cele edukacyjne dla szkoły ponadgimnazjalnej kończącej się maturą (poziom podstawowy) można uznać za związane z przedsiębiorczością (tab. 2).

Tab. 2. Cele kształcenia z zakresu geografii a kształtowanie postaw przedsiębiorczych (szkoła ponadgimnazjalna kończąca się maturą - poziom podstawowy)

\begin{tabular}{|l|l|}
\hline \multicolumn{1}{|c|}{$\begin{array}{c}\text { Cele kształcenia - wymagania ogólne } \\
\text { wg podstawy programowej }\end{array}$} & \multicolumn{1}{c|}{$\begin{array}{c}\text { Wybrane cechy i umiejętności osoby } \\
\text { przedsiębiorczej* }\end{array}$} \\
\hline $\begin{array}{l}\text { Wykorzystanie różnych źródeł informacji do } \\
\text { analizy i prezentowania współczesnych } \\
\text { problemów przyrodniczych, gospodarczych, } \\
\text { społecznych, kulturowych i politycznych. }\end{array}$ & $\begin{array}{l}\text { otwartość na otoczenie, ciekawość świata, } \\
\text { umiejętność interpretowania (analizowania) } \\
\text { procesów gospodarczych oraz rozumienia } \\
\text { związków przyczynowo-skutkowych }\end{array}$ \\
\hline $\begin{array}{l}\text { Formułowanie i weryfikowanie hipotez } \\
\text { dotyczących problemów współczesnego świata. }\end{array}$ & $\begin{array}{l}\text { umiejętność interpretowania procesów gospodar- } \\
\text { czych oraz formułowania i weryfikacji hipotez }\end{array}$ \\
\hline
\end{tabular}

*możliwe do kształtowania w toku realizacji danego celu kształcenia

Źródło: opracowanie własne na podstawie Rozporządzenie 2009. 
Treści z zakresu przedsiębiorczości mogą być realizowane w ramach realizacji lekcji dotyczących zróżnicowania gospodarki światowej. W świetle zapisów podstawy programowej jest to moduł 2:

\section{Zróżnicowanie gospodarcze świata. Uczeń:}

1) klasyfikuje państwa na podstawie analizy wskaźników rozwoju społecznego i gospodarczego; wyróżnia regiony bogate i biedne (bogatą Północ i biedne Południe) i podaje przyczyny dysproporcji w poziomie rozwoju społeczno-gospodarczego regionów świata;

2) ocenia i projektuje różne formy pomocy państwa i organizacji pozarzadowych państwom i regionom dotkniętym kryzysem (klęskami ekologicznymi, wojnami, głodem);

3) opisuje główne obszary upraw i chowu zwierząt na świecie, wyjaśnia ich zróżnicowanie przestrzenne;

4) wyjaśnia, z czego wynikają różnice w wielkości i strukturze spożycia żywności na świecie (uwarunkowania przyrodnicze, kulturowe, społeczne i polityczne, mechanizmy wpływające na nierównomierny rozdział żywności w skali globalnej);

5) opisuje zmiany w funkcji obszarów wiejskich na wybranych przykładach (np. w Unii Europejskiej, w regionach turystycznych w państwach rozwijających się); potrafi wyjaśnić szanse i zagrożenia dla środowiska przyrodniczego i mieszkańców poszczególnych regionów, wynikające z procesów przemian zachodzących na terenach wiejskich;

6) charakteryzuje kierunki zmian w powierzchni lasów na świecie (w wyniku procesów wylesiania i zalesiania) i podaje przykłady gospodarowania zasobami leśnymi (pozytywne i negatywne);

7) charakteryzuje cechy gospodarki morskiej i podaje przykłady wykorzystania oceanu światowego oraz zagrożeń wynikających ze zbyt intensywnej eksploatacji zasobów morskich;

8) charakteryzuje i ocenia zróżnicowanie i zmiany struktury wykorzystania surowców energetycznych na świecie; dokonuje oceny zjawiska uzależnienia produkcji energii na świecie od źródeł zaopatrzenia surowców nieodnawialnych, potrafi wyjaśnić twierdzenie „,ropa rządzi światem";

9) wyjaśnia, na czym polegaja zmiany zachodzace na rynku pracy w skali globalnej i regionalnej, wynikajace z rozwoju nowoczesnych technologii informacyjno-komunikacyjnych;

10) przedstawia cechy przemysłu wysokiej technologii i podaje przykłady jego lokalizacji na świecie; poznaje nowe funkcje ośrodków przemysłowych i nowe formy przestrzenne technopolie, klastry i dystrykty przemysłowe;

11) charakteryzuje wybrane obszary intensywnie zagospodarowywane turystycznie na świecie; wyjaśnia, dlaczego zmieniają się kierunki wyjazdów turystycznych Polaków; identyfikuje skutki rozwoju turystyki dla środowiska przyrodniczego;

12) ocenia rolę nowoczesnych usług komunikacyjnych w funkcjonowaniu gospodarki i w życiu codziennym;

13) wyjaśnia zmiany zachodzące w kierunkach i natężeniu ruchu osób i towarów; wskazuje przykłady lokalizacji nowoczesnych terminali i ich rolę w rozwoju regionów;

14) podaje przykłady procesów globalizacji i ich wpływu na rozwój regionalny i lokalny;

15) wyjaśnia współczesne zmiany na mapie politycznej świata;

16) wyjaśnia na wybranych przykładach (w skali lokalnej, regionalnej i globalnej) przyczyny procesów integracyjnych i ich skutki gospodarcze, społeczne i polityczne.

Podobnie w podstawie programowej dla szkoły ponadgimnazjalnej na poziomie rozszerzonym wskazać można cele edukacyjne odnoszące się do postawy przedsiębiorczej (tab. 3). 
Tab. 3. Cele kształcenia z zakresu geografii a kształtowanie postaw przedsiębiorczych (szkoła ponadgimnazjalna kończąca się maturą - poziom rozszerzony)

\begin{tabular}{|c|c|}
\hline $\begin{array}{c}\text { Cele kształcenia - wymagania ogólne } \\
\text { wg podstawy programowej }\end{array}$ & $\begin{array}{l}\text { Wybrane cechy i umiejętności } \\
\text { osoby przedsiębiorczej* }\end{array}$ \\
\hline $\begin{array}{l}\text { I. Dostrzeganie prawidłowości dotyczących środowiska przyrod- } \\
\text { niczego, życia i gospodarki człowieka oraz wzajemnych powią- } \\
\text { zań i zależności w systemie człowiek - przyroda - gospodarka. } \\
\text { Uczeń wskazuje i analizuje prawidłowości i zależności wynikają- } \\
\text { ce z funkcjonowania sfer ziemskich oraz działalności człowieka } \\
\text { w różnorodnych warunkach środowiska, wskazując znaczenie } \\
\text { rosnącej roli człowieka i jego działań w środowisku geograficz- } \\
\text { nym w różnych skalach (lokalnej, regionalnej i globalnej). }\end{array}$ & $\begin{array}{l}\text { umiejętność interpretowania } \\
\text { procesów gospodarczych } \\
\text { oraz rozumienia związków } \\
\text { przyczynowo-skutkowych }\end{array}$ \\
\hline $\begin{array}{l}\text { III. Proponowanie rozwiązań problemów występujących } \\
\text { w środowisku geograficznym, zgodnie z koncepcją zrównoważo- } \\
\text { nego rozwoju i zasadami współpracy, w tym międzynarodowej. } \\
\text { Uczeń wskazuje propozycje rozwiązań lokalnych, regionalnych } \\
\text { i globalnych problemów środowiskowych, demograficznych } \\
\text { i gospodarczych zgodnych z koncepcją zrównoważonego } \\
\text { rozwoju oraz opartych na równoprawnych zasadach współpracy } \\
\text { między regionami i państwami. }\end{array}$ & $\begin{array}{l}\text { gotowość do zdobywania wiedzy } \\
\text { i nowych umiejętności oraz } \\
\text { podejmowania nowych, niezna- } \\
\text { nych zadań, aktywność, kreatyw- } \\
\text { ność, inicjatywa, otwartość na } \\
\text { otoczenie, umiejętność interpreto- } \\
\text { wania procesów gospodarczych } \\
\text { oraz rozumienia związków } \\
\text { przyczynowo-skutkowych }\end{array}$ \\
\hline $\begin{array}{l}\text { IV. Pozyskiwanie, przetwarzanie oraz prezentowanie informacji } \\
\text { na podstawie różnych źródeł informacji geograficznej, w tym } \\
\text { również technologii informacyjno-komunikacyjnych oraz } \\
\text { Geograficznych Systemów Informacyjnych (GIS). } \\
\text { Uczeń zdobywa informacje oraz rozwija i doskonali umiejętności } \\
\text { geograficzne, wykorzystując wszystkie dostępne (w tym } \\
\text { najnowsze) źródła informacji, pomiary i obserwacje bezpośred- } \\
\text { nie; potrafi selekcjonować i przetwarzać informacje do prezenta- } \\
\text { cji wybranych zagadnień. }\end{array}$ & $\begin{array}{l}\text { umiejętność zdobywania, selekcji } \\
\text { i przetwarzania informacji oraz } \\
\text { ich prezentacji }\end{array}$ \\
\hline
\end{tabular}

*możliwe do kształtowania w toku realizacji danego celu kształcenia

Źródło: opracowanie własne na podstawie Rozporządzenie 2009.

Z wymienionymi celami związane są treści nauczania dotyczące źródeł informacji geograficznej oraz działalności gospodarczej na świecie i w Polsce, tj.:

Źródła informacji geograficznej. Uczeń:

1) klasyfikuje mapy ze względu na różne kryteria;

2) oblicza odległości w terenie oraz powierzchnię na podstawie map wykonanych w różnych skalach;

3) odczytuje i opisuje cechy środowiska przyrodniczego (np. ukształtowanie i rzeźbę terenu, budowę geologiczną) i społeczno-gospodarczego (np. rozmieszczenie zasobów naturalnych, ludności, szlaki transportowe) na podstawie map: topograficznej, hipsometrycznej i tematycznej;

4) interpretuje zjawiska geograficzne przedstawiane na wykresach, w tabelach, na schematach i modelach;

5) formułuje zależności przyczynowo-skutkowe, funkcjonalne i czasowe między wybranymi elementami środowiska przyrodniczego i społeczno-gospodarczego oraz dokonuje ich weryfikacji, wykorzystując mapy tematyczne; 
6) przeprowadza badania wybranych elementów środowiska geograficznego w regionie zamieszkania według przygotowanego planu;

7) stosuje wybrane metody kartograficzne do prezentacji cech ilościowych i jakościowych środowiska geograficznego;

8) korzysta z technologii informacyjno-komunikacyjnych w celu pozyskiwania, przechowywania, przetwarzania i prezentacji informacji geograficznych.

Działalność gospodarcza na świecie. Uczeń:

1) wyjaśnia wpływ czynników przyrodniczych i społeczno-ekonomicznych na rozwój rolnictwa;

2) wykazuje zależności między rodzajami produkcji rolnej a warunkami naturalnymi i rozmieszczeniem ludności oraz charakteryzuje różne typy rolnictwa na świecie;

3) wskazuje problemy związane z upowszechnianiem się roślin uprawnych zmodyfikowanych genetycznie i wskazuje rejony ich upraw;

4) porównuje i uzasadnia strukturę spożycia żywności w państwach wysoko i słabo rozwiniętych;

5) uzasadnia konieczność racjonalnego gospodarowania zasobami leśnymi na świecie;

6) wskazuje możliwości rozwoju wykorzystania zasobów oceanów i mórz;

7) charakteryzuje zmiany w strukturze zużycia energii postepujace wraz z rozwojem gospodarczym państw świata i ocenia skutki wynikajace z rosnacego zużycia energii oraz konieczność pozyskiwania nowych źródeł energii;

8) wskazuje wpływ czynników lokalizacji przemysłu na rozmieszczenie i rozwój wybranych branż;

9) uzasadnia różnice ilościowe i jakościowe produkcji przemysłowej państw na różnym poziomie rozwoju gospodarczego i ocenia wpływ przemysłu zawansowanych technologii na rozwój gospodarczy i jakość życia;

10) charakteryzuje znaczenie usług materialnych i niematerialnych;

11) planuje i prowadzi badania zróżnicowania usług w miejscu zamieszkania;

12) przedstawia, na podstawie danych statystycznych, poziom zaspokojenia potrzeb na usługi podstawowe i wyspecjalizowane w państwach o różnym poziomie rozwoju gospodarczego;

13) analizuje kierunki geograficzne i strukture towarowa eksportu i importu w wybranych państwach;

14) wskazuje i uzasadnia pozytywne i negatywne skutki globalizacji i integracji politycznej;

15) wyjaśnia przyczyny i przebieg konfliktów zbrojnych w wybranych regionach współczesnego świata.

Geografia Polski - działalność gospodarcza. Uczeń:

1) ocenia poziom wykorzystania warunków naturalnych na podstawie wielkości i rodzajów produkcji rolniczej w porównaniu z innymi państwami Unii Europejskiej;

2) wskazuje zmiany strukturalne zachodzace w polskim rolnictwie;

3) wskazuje obszary wystepowania podstawowych zasobów naturalnych i analizuje zmiany wielkości ich eksploatacji;

4) porównuje wielkość i strukturę produkcji energii elektrycznej w Polsce i innych państwach świata;

5) wskazuje dziedziny produkcji przemysłowej dynamicznie się rozwijające;

6) przedstawia zmiany w gospodarce Polski spowodowane jej restrukturyzacja i modernizacją po $1990 \mathrm{r}$;

7) wskazuje przykłady i znaczenie inwestycji zagranicznych w Polsce dla rozwoju społeczno-gospodarczego kraju;

8) przedstawia zróżnicowanie sektora usług w Polsce i innych państwach Unii Europejskiej; 
9) podaje przykłady przekształceń własnościowych w polskiej gospodarce mające wpływ na zmiany struktury produkcji i stopień zaspokojenia potrzeb materialnych i usług;

10) wskazuje głównych partnerów handlowych oraz kierunki geograficzne i strukturę towarowa wymiany międzynarodowej Polski.

W zapisach podstawy programowej wyraźnie widać, że na lekcjach geografii realizowane są treści, które pozwalają zrozumieć wpływ różnorodnych czynników, w tym także przyrodniczych, na funkcjonowanie gospodarki w różnych skalach przestrzennych (światowej, krajowej, regionalnej i lokalnej), co ma duże znaczenie z punktu widzenia kompetencji przydatnych w podejmowaniu działalności gospodarczej. Rozumienie przez właściciela (menedżera) procesów i relacji pomiędzy elementami przestrzeni geograficznej (w tym przestrzeni przyrodniczej, społeczno-gospodarczej i kulturowej) jest warunkiem dobrego zarządzania firmą. To przedsiębiorca, na podstawie odpowiednio przygotowanych prac diagnostycznych, których dostarczają studia geograficzne, musi podejmować określone decyzje o kierunkach rozwoju firmy. Dzięki lekcjom geografii uczeń (przyszły przedsiębiorca lub menedżer firmy) zostaje wdrożony w myślenie o rozwoju gospodarczym, oparte na - w swej istocie aprzestrzennych - regułach ekonomicznych, odmiennie realizujących się w konkretnych geograficznych uwarunkowaniach danego układu przestrzennego.

Należy zwrócić uwagę, że w nowych uwarunkowaniach rozwoju społeczno-gospodarczego związanych z budową gospodarki opartej na wiedzy, procesami globalizacyjnymi i integracyjnymi, a w warunkach polskich również transformacyjnymi, zmienia się przedmiot badań geograficznych, a także cele i treści kształcenia geograficznego, w których coraz większą rolę przypisuje się przedsiębiorcy. Współczesna definicja geografii zmierza w kierunku traktowania jej jako „nauki o zarządzaniu przestrzenią geograficzną”, w której przedsiębiorczość będzie odgrywać coraz poważniejszą rolę. Należy bowiem przyjąć, że procesy przemian społeczno-gospodarczych i kulturowych, a także zmiany warunków przyrodniczych, wynikają z podejmowania określonych decyzji, u podstaw których leży przedsiębiorczość określonych osób (w tym przedsiębiorców) czy przedstawicieli władz samorządowych i centralnych. Dlatego współczesna geografia obejmuje coraz szerzej swoim przedmiotem badan działalność przedsiębiorczą, która w warunkach gospodarki rynkowej jest podstawą przemian i podnoszenia jakości życia społeczeństwa w różnej skali układów przestrzennych. Przedsiębiorczość jest podstawowym czynnikiem podnoszenia ich pozycji konkurencyjnej. Dlatego coraz więcej treści z tego zakresu jest włączanych w cele i treści kształcenia geografii na różnych poziomach geograficznych, a problematyka przedsiębiorczości wykazuje coraz silniejsze związki z geografią (Rachwał, Zioło 2010).

Istotną rolę w kształtowaniu postaw przedsiębiorczych powinny odgrywać organizowane przez nauczyciela geografii wycieczki pozaszkolne. Szczególnie pomocne może być tu przesuwanie uprawnień i zadań z tym związanych na uczniów (m.in. projektowanie trasy wycieczki, zamawianie noclegów, koordynacja spraw związanych z transportem, wyżywieniem itd.). W pewnym stopniu można $\mathrm{w}$ tę pracę zaangażować już uczniów gimnazjum, ale dużo większe możliwości ma nauczyciel w szkole ponadgimnazjalnej. Wycieczki, poza szerokimi możliwościami kształtowania postaw przedsiębiorczych, sprzyjają kształtowaniu umiejętności pracy zespołowej uczniów. Jak podkreśla bowiem Z. Pisz: „edukacja szkolna ma do spełnienia zadania związane z kształtowaniem wszystkich cech jednostek, które ułatwiają funkcjonowanie w grupie, współpracowanie w zespołach, a także umożliwiają zrozumienie i akceptację odmienności, wynikających między innymi z zajmowanej pozycji i spełnianych ról społecznych oraz odrębności kulturowych” (Pisz 2003, s. 173). 
Zmiany w sferze edukacyjnej powinny zmierzać zatem do otwartego i elastycznego systemu kształcenia, który wspiera aktywność poznawczą oraz szeroko rozumianą przedsiębiorczość, także na innych przedmiotach, a nie tylko na lekcjach podstaw przedsiębiorczości. Szczególną rolę w tym zakresie odgrywają lub powinni odgrywać nauczyciele geografii.

\section{Literatura}

1. Borowiec M., 2003, Kształtowanie się krakowskiego ośrodka akademickiego w latach 1960-2001 [w:] Geograficzne aspekty globalizacji i integracji europejskiej, M. Śmigielska, J. Słodczyk (red.), Wydawnictwo Polskiego Towarzystwa Geograficznego, Uniwersytet Opolski, Opole.

2. Borowiec M., 2005, Rola praktyk z przedsiębiorczości w kształceniu studentów geografii na specjalności ,przedsiębiorczość z gospodarka przestrzenna” [w:] Przedsiębiorczość a współczesne wyzwania cywilizacyjne, Z. Zioło, T. Rachwał (red.), „Przedsiębiorczość - Edukacja”, nr 1, Wydawnictwo MiWa, Zakład Przedsiębiorczości i Gospodarki Przestrzennej Instytutu Geografii Akademii Pedagogicznej w Krakowie, Kraków.

3. Borowiec M., 2009, Rola edukacji w ksztaltowaniu spoleczeństwa informacyjnego [w:] Rola przedsiębiorczości w kształtowaniu społeczeństwa informacyjnego, Z. Zioło, T. Rachwał (red.), „Przedsiębiorczość - Edukacja”, nr 5, Nowa Era, Zakład Przedsiębiorczości i Gospodarki Przestrzennej Instytutu Geografii Uniwersytetu Pedagogicznego w Krakowie, Warszawa-Kraków.

4. Borowiec M., 2010, Funkcjonowanie krakowskiego i rzeszowskiego ośrodka akademickiego w świetle koncepcji uktadów bipolarnych, „Prace Monograficzne” nr 539, Wydawnictwo Uniwersytetu Pedagogicznego w Krakowie.

5. Chojnicki Z., Czyż T., 2008, Gospodarka oparta na wiedzy w regionach metropolitalnych i aglomeracjach miejskich $w$ Polsce [w:] Rola polskich aglomeracji wobec wyzwań strategii lizbońskiej, T. Marszał (red.), Studia KPZK PAN, Tom CXX, Warszawa.

6. Grodzicki J., 2000, Edukacja czynnikiem rozwoju gospodarczego, Wydawnictwo Adam Marszałek, Toruń.

7. Harańczyk A., 2008, Potencjał rozwojowy szkót wyższych Małopolski [w:] Rola przedsiębiorczości w procesie ksztaltowania gospodarki opartej na wiedzy, Z. Zioło, T. Rachwał (red.), „Przedsiębiorczość - Edukacja”, nr 4, Nowa Era, Zakład Przedsiębiorczości i Gospodarki Przestrzennej Instytutu Geografii Uniwersytetu Pedagogicznego w Krakowie, Warszawa-Kraków

8. Janc K., 2003, Rola nauki i techniki we współczesnym świecie [w:] Geograficzne aspekty globalizacji i integracji europejskiej, M. Śmigielska, J. Słodczyk (red.), PTG Uniwersytet Opolski, Opole.

9. Jeruszka U., 2001, Szkoła zawodowa w perspektywie integracji europejskiej [w:] Edukacja w perspektywie integracji europejskiej, M. Ochmański, T. Sokołowska-Dzioba, A. Pielecki (red.), Wydawnictwo WSP Towarzystwa Wiedzy Powszechnej, Warszawa 2001.

10. Juszkiewicz N., 1997, Nauka i technika jako czynniki rozwoju Poznania, UAM, Poznań.

11. Kabaj M., 1997, W kierunku gospodarki opartej na wiedzy, „Polityka Społeczna”, nr 4.

12. Kafel T., 2005, Wyższe uczelnie ekonomiczne w procesie podnoszenia konkurencyjności przedsiębiorstw: nowe warunki, nowe możliwości [w:] Strategia lizbońska a konkurencyjność gospodarki, J. Bieliński (red.), Wydawnictwa Fachowe CeDeWu.Pl, Warszawa.

13. Kołodziejski J., 1998, Strategiczna koncepcja przeksztatceń polskiej przestrzeni a wyzwania cywilizacyjne XXI w. [w:] Współczesne problemy rozwoju regionalnego, T. Marszał i M. Opałło (red.), Biuletyn KPZK PAN, Warszawa, z. 180.

14. Kuźnicki L., 2004, Polska w obliczu wyzwań przyszłości. W świetle studiów Komitetu Prognoz „Polska 2000 Plus” Polskiej Akademii Nauk, Komitet Prognoz „Polska 2000 Plus” przy Prezydium Polskiej Akademii Nauk, ELIPSA, Warszawa. 
15. Pisz Z., 2003, Problemy społeczne edukacji na Ślasku Opolskim [w:] W odpowiedzi na zjawiska $i$ wyzwania społeczne, K. Frysztacki, K. Heffner (red.), Opole.

16. Rachwał T., 2004, Podstawy przedsiębiorczości - słownik dla liceum ogólnokształcacego, liceum profilowanego i technikum. Nowa Era, Warszawa.

17. Rachwał T., 2005, Ksztaltowanie postaw uczniów na lekcjach podstaw przedsiębiorczości [w:] Przedsiębiorczość a wspótczesne wyzwania cywilizacyjne, Z. Zioło, T. Rachwał (red.), „Przedsiębiorczość - Edukacja”, nr 1, Wydawnictwo MiWa, Zakład Przedsiębiorczości i Gospodarki Przestrzennej Instytutu Geografii Akademii Pedagogicznej w Krakowie, Kraków.

18. Rachwał T., Zioło Z., 2010, III. Rozwój naukowo-dydaktyczny i problematyka badań w zakresie dyscyplin towarzyszacych - 3. Przedsiębiorczość [w:] Rozwój naukowo-dydaktyczny i kierunki badawcze Instytutu Geografii Uniwersytetu Pedagogicznego im. Komisji Edukacji Narodowej w Krakowie, Z. Długosz, Z. Zioło (red.), Wydawnictwo Naukowe UP, Kraków.

19. Rozporzadzenie Ministra Edukacji Narodowej z dnia 23 grudnia 2008 r. w sprawie podstawy programowej wychowania przedszkolnego oraz kształcenia ogólnego w poszczególnych typach szkót, 2009 (Dz.U. z dn. 15 stycznia 2009 r., nr 4, poz. 17).

20. Strategia rozwoju edukacji na lata 2007-2013, sierpień 2005, Ministerstwo Edukacji Narodowej i Sportu, Warszawa.

21. Wieloński A., 2003, Przemyst Nowej Gospodarki [w:] Przemyst w procesie globalizacji, Z. Zioło, Z. Makieła (red.), „Prace Komisji Geografii Przemysłu PTG”, nr 6, Warszawa-Kraków.

22. Narodowy plan rozwoju 2007-2013 (wstępny projekt), 2005, www.npr.gov.pl.

23. Zajączkowska-Jakimiak S., 2002, Wiedza i technologia w erze globalizacji [w:] Globalizacja, mechanizmy $i$ wyzwania, B. Liberska (red.), PWE, Warszawa.

24. Zioło I., 1999, Wybrane atrybuty wartości edukacyjnej wyższej szkoły niepaństwowej [w:] Problemy przemian układów regionalnych, Z. Zioło (red.), cz. II, „Zeszyty Naukowe Wyższej Szkoły Informatyki i Zarządzania w Rzeszowie", nr 3, Rzeszów.

25. Zioło Z., 2009, Rola przedsiębiorczości w ksztaltowaniu społeczeństwa informacyjnego [w:] Rola przedsiębiorczości $w$ kształtowaniu społeczeństwa informacyjnego, Z. Zioło, T. Rachwał (red.), „Przedsiębiorczość-Edukacja”, nr 5, Zakład Przedsiębiorczości i Gospodarki Przestrzennej Instytutu Geografii Uniwersytetu Pedagogicznego w Krakowie, Nowa Era, Warszawa-Kraków.

26. Zioło Z., 2010, Rola zasobów intelektualnych, kapitału ludzkiego i społecznego w procesach rozwoju obszarów wiejskich [w:] Kapitał ludzki i społeczny w procesie rozwoju obszarów wiejskich, W. Kamińska, K. Heffner (red.), Studia KPZK PAN T. CXXVI, Warszawa.

\section{Developing Entrepreneurial Attitudes on Geography Lessons as an Educational Challenge in the Globalization Process}

The paper aims to highlight the role of entrepreneurial attitudes in school education. This is due to the large role of entrepreneurship in the socio-economic development of different spatial systems (local, regional, national) in a globalized world economy. Developing entrepreneurial attitudes should take place not only during the lessons of Entrepreneurship, but during the whole period of school education and on other subjects. Teachers of Geography play a special role in this field. It is the consequence of large convergence of aims and teaching contents of geographic education with the objectives of entrepreneurship education. 